\title{
Changing patterns of West Nile virus transmission: altered vector competence and host susceptibility
}

\author{
Aaron C. BraulT ${ }^{* * * *}$ \\ Center for Vector-Borne Diseases and Department of Pathology, Microbiology and Immunology, \\ School of Veterinary Medicine, University of California, 5327 VM3A, \\ One Shields Ave, Davis, CA 95616, USA
}

(Received 4 February 2009; accepted 29 April 2009)

\begin{abstract}
West Nile virus (WNV) is a flavivirus (Flaviviridae) transmitted between Culex spp. mosquitoes and avian hosts. The virus has dramatically expanded its geographic range in the past ten years. Increases in global commerce, climate change, ecological factors and the emergence of novel viral genotypes likely play significant roles in the emergence of this virus; however, the exact mechanism and relative importance of each is uncertain. Previously WNV was primarily associated with febrile illness of children in endemic areas, but it was identified as a cause of neurological disease in humans in 1994. This modulation in disease presentation could be the result of the emergence of a more virulent genotype as well as the progression of the virus into areas in which the age structure of immunologically naïve individuals makes them more susceptible to severe neurological disease. Since its introduction to North America in 1999, a novel WNV genotype has been identified that has been demonstrated to disseminate more rapidly and with greater efficiency at elevated temperatures than the originally introduced strain, indicating the potential importance of temperature as a selective criteria for the emergence of WNV genotypes with increased vectorial capacity. Even prior to the North American introduction, a mutation associated with increased replication in avian hosts, identified to be under adaptive evolutionary pressure, has been identified, indicating that adaptation for increased replication within vertebrate hosts could play a role in increased transmission efficiency. Although stable in its evolutionary structure, WNV has demonstrated the capacity for rapidly adapting to both vertebrate hosts and invertebrate vectors and will likely continue to exploit novel ecological niches as it adapts to novel transmission foci.
\end{abstract}

West Nile virus / vector competence / temperature / host competence / virus-host interaction

\section{Table of contents}

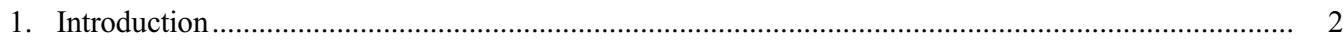

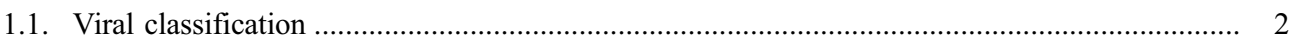

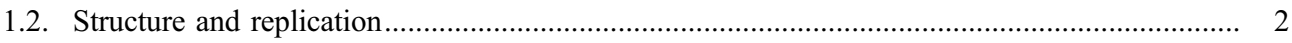

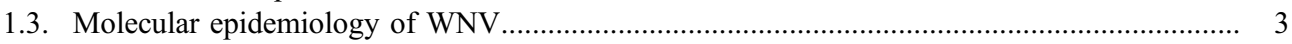

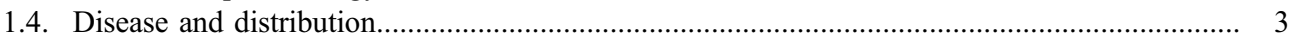

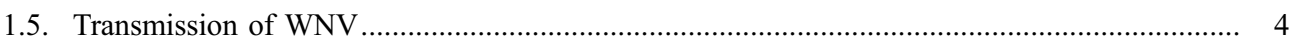

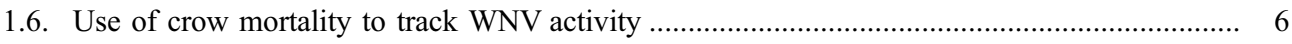

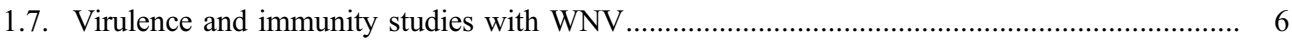

\footnotetext{
*Corresponding author: acbrault@ucdavis.edu, abrault@cdc.gov

${ }^{* *}$ Current address: Division of Vector-Borne Infectious Diseases, Centers for Disease Control and Prevention, 3150 Rampart Rd/Foothills Campus, Fort Collins, CO 80521, USA
} 


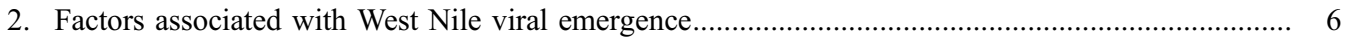

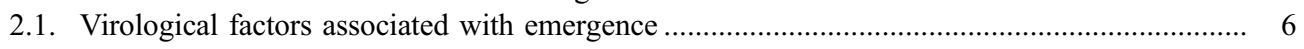

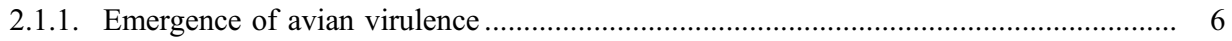

2.1.2. Genotype associated with avian virulence .............................................................. 7

2.1.3. Increased virulence as a factor for increased transmission.......................................... 8

2.1.4. Viral adaptation for replication at higher temperature .............................................. 9

2.2. Environmental factors associated with emergence............................................................ 10

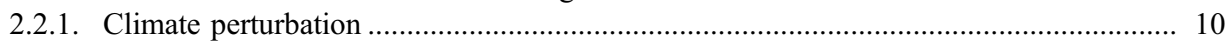

2.2.2. Species diversity, species behavior and transmission dynamics.................................. 10

2.2.3. Role of heterologous flaviviruses on WNV transmission ........................................... 11

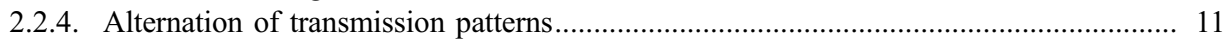

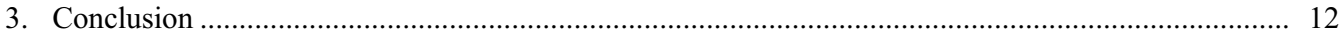

\section{INTRODUCTION}

The purpose of this review is to present some of the potential factors that have been associated with the emergence of West Nile virus (WNV) from an endemic virus, generally associated with childhood disease, to an agent that has rapidly expanded its geographic range, becoming established in the New World with novel, more serious disease manifestations. Ecological, virological, epidemiological and entomological avenues are explored to address this phenomenon.

\subsection{Viral classification}

West Nile virus is a member of the genus Flavivirus within the family Flaviviridae [59] and was first isolated from a human experiencing a febrile syndrome in the West Nile district of Uganda in 1937 [142]. Serological cross reactivity has grouped WNV within the Japanese encephalitis (JE) virus serocomplex [27]. In addition to $\mathrm{WNV}$, the JE serocomplex includes three other viral species responsible for human disease including Japanese encephalitis (JEV), St. Louis encephalitis (SLEV) and Murray Valley encephalitis (MVEV) viruses [94].

Despite the name "serocomplex", classification of these viruses is based on a combination of serological cross reactivity, nucleotide sequence data, and vector association [59]. The WNV species contains one viral subtype (Kunjin), comprised of isolates from Australia and Malaysia [157]. West Nile viruses have a pandemic distribution having been isolated on every continent with the exception of Antarctica [57]. Despite the fact that serological assays distinguish WNV isolates from India as well as Kunjin from other WNV, only Kunjin is classified as a distinct viral subtype [156]. Nucleotide sequence data has subsequently demonstrated Kunjin viruses to have a greater genetic identity with newly emergent WNV genotypes than Old World strains including those from India [115, 135]. Altered serological reactivity is most likely due to the lack of an additional glycosylation motif within the envelope glycoprotein of Kunjin viruses [1].

\subsection{Structure and replication}

West Nile virus is comprised of an enveloped spherical virion with a diameter of approximately $50 \mathrm{~nm}$. The virus has a linear, single-stranded, message-sense genome of approximately $11 \mathrm{~Kb}$ with a 5'(7-methyguanosine) cap and no polyadenylation at the $3^{\prime}$ end of the genome [129]. The $5^{\prime}$ and $3^{\prime}$ non-coding regions (NCR) have conserved nucleotide elements that form stem-loop structures necessary for viral RNA transcription, translation and packaging [25, 72, 139]. Viral proteins are translated as a single polyprotein that is posttranslationally cleaved by host and viral proteases to produce 3 structural $(\mathrm{C}$, prM and $\mathrm{E})$ and 7 nonstructural proteins (NS1, NS2A, NS2B, NS3, NS4A, NS4B and NS5). The $5^{\prime}$ third of the genome encodes the structural 


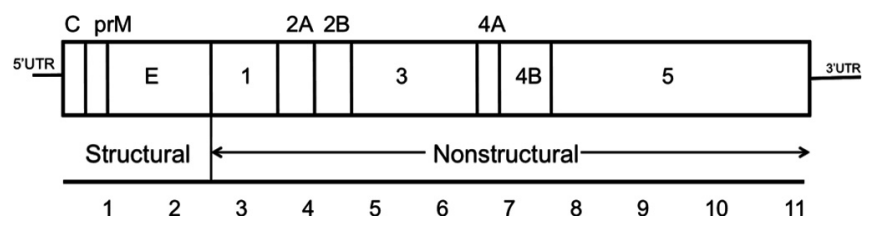

Figure 1. Genomic organization of the WNV genome. Three structural proteins (C, prM, E) and seven nonstructural proteins (NS1, 2A, 2B, 3, 4A, 4B and 5) are translated as a single polyprotein directly from the $11 \mathrm{~Kb}$ positive-sense RNA genome.

proteins necessary for encapsidation of the viral RNA and the surface proteins required for viral receptor interaction and fusion with host cells (Fig. 1) [76]. The remainder of the genome encodes the nonstructural proteins that form the viral replication complex for the generation of negative-sense template RNA as well as positive-sense genomic RNA [161]. The largest of the NS proteins, NS3 and NS5, have been characterized for interactions and replicase activity; however, the function of the remaining NS proteins is largely unknown. The NS5 protein has both RNA polymerase and methyltransferase motifs necessary for viral replication. Helicase and serine protease domains have been described for the NS3 protein [129]. Interestingly, the NS1 protein is a secretory nonstructural protein that does not have a designated function in RNA replication or as a control element [162].

\subsection{Molecular epidemiology of WNV}

Phylogenetic trees based on nucleotide sequence data indicate the existence of five potentially distinct genetic lineages of WNV that have diverged by up to $29 \%$ at the nucleotide level $[18,89]$. Sequence analysis of viral strains from North America, Africa, the Middle East, Asia, and Australia (Kunjin) constitute lineage 1 based on structural [18, 63, 89] or nonstructural gene regions [14, 29]. Phylogenetic analyses clearly indicate that Kunjin is a member of lineage 1 and that the second lineage WNV, restricted to a sub-Saharan African distribution, are more distantly related to other lineage $1 \mathrm{WNV}$ than to Kunjin virus [135]. Lineage $3 \mathrm{WNV}$ is represented by a Czech Republic mosquito isolate (Rabensburg; RabV)
[11], lineage 4 is comprised of Dermacentor spp. tick isolates from the Russian Caucasus [117], and lineage 5 is represented by a separate genotype from India [21]. Phylogenetic grouping of isolates does not correlate with geographic distribution, indicating the potential importance of birds in viral dispersal [18].

All of the major outbreaks of human encephalitis have been associated with viruses genetically categorized as lineage 1, making an important correlation between viral genetics and disease phenotype. The preponderance of genetic evidence suggests that the introduction of WNV into North America occurred from the Middle East. Complete genomic sequencing of an isolate from an outbreak in geese in Israel in 1998 and NY99 strains of WNV group them in the same genetic clade with a $99.7 \%$ shared nucleotide identity $[29,90]$. The identification of bird carcasses found to be positive for WNV from a number of species in Israel provides evidence that naturally occurring bird virulent strains could be circulating within the Middle East and were introduced into North America [95].

\subsection{Disease and distribution}

Clinical disease in humans ranges from mild fever to the development of severe neurological disease [143]; however, retrospective serological studies have indicated that the majority of WNV infections are actually asymptomatic [6, 154]. West Nile fever is the most common clinical manifestation and is characterized by the development of high fever, chills, rash, headache, myalgia and nausea. Symptoms typically abate within 3-5 days of onset and result in lifetime immunity. WNV infection also may result in 
the development of severe neurological symptoms that include encephalitis, meningitis, myelitis or combinations of these symptoms $[58,98]$. Acute flaccid paralysis of the limbs and respiratory muscles has been described in North America [8] and Romania [28].

Elderly individuals are at a greater risk for developing severe neurological disease, with younger patients more commonly developing WN fever [106]. It is not readily clear whether the more severe neurological symptoms are the result of increased virulence of the introduced strain or a reflection on the immunologically naive status of the population whose age structure might be more predisposed to severe disease manifestations. Postulated mechanisms of viral entry to the CNS and subsequent development of more severe disease include impaired structural elements of the blood-brain barrier (BBB) or impaired immunity with increased age [143]; however, data generated with microvascular endothelial cells indicates the maintenance of $\mathrm{BBB}$ integrity following infection with $\mathrm{WNV}$, indicating the potential of free virus to pass this barrier. Furthermore, increased cell adhesion molecule expression observed in this study indicated the potential for infected immune cells to also traverse the BBB [158].

West Nile virus has been found to be endemic to Europe [80], Africa [45, 101], Asia and Australasia [69]. Within its geographic range, outbreaks of febrile disease in humans have occurred sporadically with well documented outbreaks being reported in Egypt [149], France [64] and South Africa [68] with outbreaks occurring in 2008 in Romania [116], Hungary [84] and Italy [93, 133]. Like in the USA $[4,5,7]$, recent disease outbreaks occurring in Romania [154], Italy [10, 104], Russia [92] and Israel [30] have been associated with the severe disease symptomology. Since its introduction to the USA in 1999, a total of 28975 human cases including 1124 deaths (through 2008) have been documented (www.cdc.gov).

West Nile virus has demonstrated a wide host range, infecting, for example, equines, alligators [62], dogs [9], sheep [71], llamas [86], alpacas [35, 87]; however, few animals consistently demonstrate overt disease. The attack rate for equines is approximately 5\% with an estimated 1 in 3 horses that demonstrate encephalitis succumbing to the disease $[10,26]$. Other than birds, some squirrel $[51,60,78,111$, 113], chipmunk [112] and rabbit species [153], and potentially alligators [79] most serve as dead-end hosts in which circulating viremias are not sufficient for infection of mosquito vectors.

\subsection{Transmission of $\mathrm{WNV}$}

Since its identification in 1937 from the West Nile district in Uganda [142], WNV transmission cycles have been extensively described in Egypt [149], South Africa [68], Israel [109] and Pakistan [3, 55, 121]. These maintenance cycles have all included ornithophilic mosquito species and mostly passerine avian hosts (Fig. 2) that maintain sufficient viremias for the infection of subsequent mosquitoes. Isolations have been made most extensively from mosquitoes of the genus Culex, not only in Egypt [148] but also throughout its pandemic distribution [121]. In South Africa, although isolations have been made from a wide range of mosquitoes, Culex univittatus is the only mosquito vector that is efficiently infected at titers that are present in birds infected with WNV. The role of alternative mosquito populations in viral transmission is presumably quite low $[66,67]$. In endemic transmission foci of Australia, Culex annulirostris is the major mosquito vector [53], while the Culex vishnui complex and Culex tritaeniorhynchus have been implicated with transmission in India and Pakistan [3, 102]. Evidence of seroconversions of birds in endemic foci [81, 100, 165] and viremia [164] and antibody [22] production following experimental inoculation of bird species has incriminated avian hosts as the vertebrate reservoir for WNV throughout its distribution. Additionally, certain mammalian species have been found to, in some cases, develop sufficient viremia for infection of mosquito vectors $[112,113$, 132]; however, the role that these hosts play in the transmission dynamics of WNV are currently uncertain but of significant interest due to the potential infection of mammalophagic mosquito vectors. 


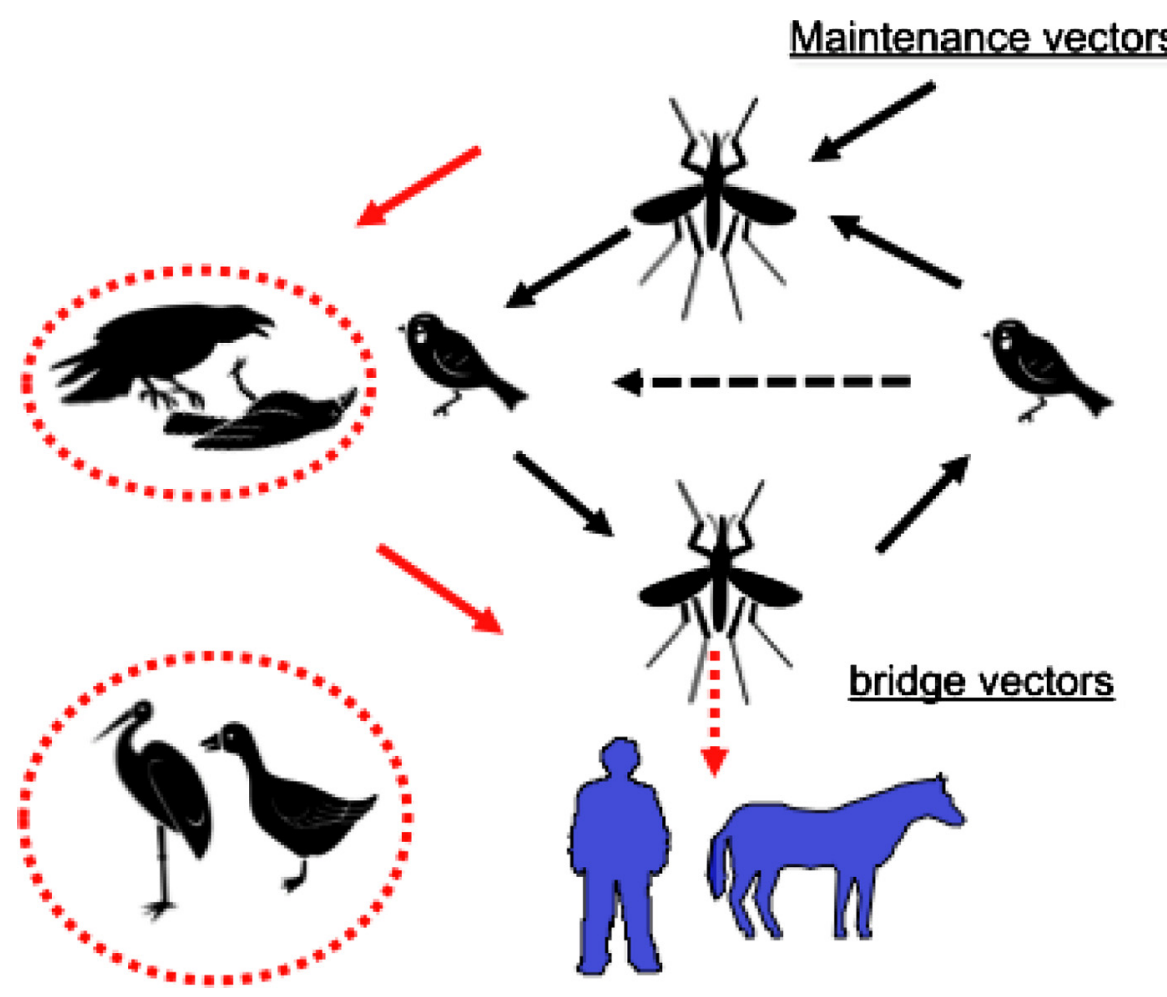

Figure 2. Transmission cycles of WNV. Transmission occurs between ornithophilic mosquito species (Culex spp.) and passeriform avian hosts. Birds typically manifest high viremias capable of exceeding oral infection thresholds for many mosquito vectors. Humans and equines fail to generate sufficient viremia for the infection of mosquito hosts and are deemed "dead end" or tangential hosts. Red: Avian mortality was first identified in a migratory stork and subsequently in commercially farmed geese in the late 1990s and has subsequently been associated with widespread mortality among numerous North American avian species (in particular, corvids). (A color version of this figure is available at www.vetres.org.)

Bird mortality has been a unique epidemiological finding for WNV transmission in Israel [19] and North America [131], having never before been reported during outbreaks of $\mathrm{WN}$ fever in Europe [134] the Middle East [105] or with endemic transmission in Australia [53] or South Africa [68] (Fig. 2). In contrast to Old World transmission, isolations of WNV have been made from numerous species of North American mosquitoes representing 11 genera. Mosquitoes most commonly infected in the eastern USA have been members of the Culex pipiens species complex, and this species complex was also associated with transmission during a human urban epidemic in Romania in 1996 [154]. However, isolations have been made from marginally competent vectors such as the catholic vectors Aedes albopictus and Aedes vexans [155].

In North America, West Nile virus rapidly expanded its geographic range from four states in 1999 to all contiguous 48 and Canada by 2004 [120]. With this westward transition, WNV has adopted Culex tarsalis as its predominant rural vector in western North America. The mechanism for viral dispersal has not been experimentally addressed; however, the extremely high viremia titers present within both resident and migratory bird species $(>150)$ indicate the probable role of some of these bird 
taxa in viral dissemination [131] with the potential for limited local dispersal by mosquitoes [118].

\subsection{Use of crow mortality to track WNV activity}

Deaths in American crow (AMCR) were especially prevalent in New York City in 1999 [4] and monitoring of crow mortality has been adopted as an epidemiological indicator for the tracking of WNV transmission in the USA and has proven useful in predicting increased risk for human infections [39, 40, 65]. Dead crows with confirmed WNV infections preceded the first human cases by three months in New York in 2000. Despite this fact, there is no knowledge regarding the genetic and/or pathological mechanism(s) of susceptibility for WNV in crows or any other bird species.

\subsection{Virulence and immunity studies with WNV}

West Nile virus neurovirulence has been studied in primate [114] as well as mouse [13, $52,160]$ and hamster models [166]. Age-related resistance to neuroinvasion is typical of mosquito-borne flaviviruses [42, 48]; however, intraperitoneal infection of 15-16 week-old mice and adult hamsters with the newly introduced North American genotype induces fatal encephalitis [13]. This finding is in contrast to a study in which WNV encephalitis was rare in mice older than 7 weeks of age following inoculation with a WNV strain from Egypt [160]. Genetic mapping studies have indicated the importance of the IFN-inducible $2^{\prime}-5^{\prime}$-oligoadenylate synthetase genes with resistance to WNV infection [99].

Development of encephalitis is identified at or near the time of clearance of virus from the peripheral circulation concurrent with the production of neutralizing antibody in a hamster model of WNV encephalitis. This model has also demonstrated that hematogenous spread of the virus across the blood-brain barrier is the most likely route of entry to the brain as the olfactory ganglia were not reported to have become infected [166]. Intranasal inoculation is a highly inefficient mode of inducing neurovirulence in mice, further indicating that infection of the olfactory bulb is likely not the most efficient mechanism of viral entry to the brain [13, 52, 110]. Inoculation of mice with different WNV strains has demonstrated a correlation between viral genotype and neurotropism [13]; however, genotypes with increased neurotropism do not correlate with increased binding to either human or mouse brain receptor preparations $[12,107]$. Unlike AMCR that have generated titers of up to $10 \log _{10} \mathrm{PFU} / \mathrm{mL}$ serum and uniformly succumb to infection within 5 days of infection [83], hamsters have peak viremias of approximately $5 \log _{10}$ $\mathrm{TCID}_{50} / \mathrm{mL}$ of serum, have approximately $50 \%$ survival rates and typically die 7-14 days after infection with the NY99 WNV genotype [166]. Antibody development may play an important role in protecting hamsters from potentially fatal encephalitis, since peripheral viral titers dissipate as circulating neutralizing antibody is produced $[151,166]$. Immunization of hamsters with heterologous flaviviruses such as Japanese encephalitis and St. Louis encephalitis viruses has demonstrated a protective effect against lethal encephalitis [152]. Administration of anti-flaviviral antibodies within 4-6 days post-infection has also been demonstrated to be efficacious for preventing flaviviral encephalitis in a mouse model [130]. This time frame correlates with viral invasion of neural tissues $[52,130,166]$. Intraperitoneal inoculation of WNV in a hamster model also demonstrates that serum neutralizing antibody development within five days of inoculation correlates with decreased peripheral viral circulation [166].

\section{FACTORS ASSOCIATED WITH WEST NILE VIRAL EMERGENCE}

\subsection{Virological factors associated with emergence}

\subsubsection{Emergence of avian virulence}

An Egyptian strain, Ar-248, was isolated from a moribund pigeon (Columba livia) squab in a field study conducted from 1952-1954. 
This strain produced morbidity and mortality in experimentally infected hooded crows (Corvus corone) and house sparrows (Passer domesticus) [164]. High seroprevalence rates within hooded crow populations in Egypt coupled with the rapid deaths of the experimentally inoculated bird (some within 1 to 2 days of infection), indicate the possibility that mortality could have been the result of experimental handling of the birds rather than natural virulence from infection [149].

No reports of natural WNV-associated mortality in adult birds occurred during the first six decades since the discovery of the virus in 1937 [57]. However, significant avian morbidity and mortality have been recent hallmarks of WNV outbreaks in Israel $[19,147]$ and North America [17]. In 1998, WNV was identified in tissues taken from dead migratory storks in Israel [97] and later that year, an outbreak within goose farms across Israel was identified. Affected flocks had severe mortality rates in goslings between 3 and 8 weeks of age [96]. Experimental infection of goslings with viruses later isolated from North America demonstrated similar mortality and resulted in viremias that were sufficient to infect mosquito vectors [147]. Evaluation of the virulence of WNV isolated from New York in 1999 demonstrated mortality in 8 of 25 species experimentally infected. The most susceptible species were the blue jay (Cyanocitta cristata), common grackle (Quiscalus quiscula), house finch (Carpodacus mexicanus), AMCR (Corvus brachyrhynchos), and house sparrow (Passer domesticus). Corvids (including AMCR, blue jays and magpies) all developed circulating viremias in excess of $8 \log _{10}$ PFU/mL blood and in some cases exceeded $10 \log _{10}$ PFU/mL blood [83]. Necropsy tissues taken from naturally [145] and experimentally infected [83] AMCR have demonstrated that the North American $\mathrm{WNV}$ is not limited to infection of particular organ systems, with virus being identified in the brain, heart, kidney, lungs, gonads, spleen, liver, intestines, esophagus and skin.

High mortality rates in AMCR and the quantity of virus identified in various organs have been factors for the adoption of crow mortality as a surveillance tool to identify areas with recent WNV activity [39, 40]. WNV infection with the NY99 genotype has been identified in more than 150 species of birds representing over 20 bird families in North America, causing morbidity in some cases but not necessarily mortality [82, 83, 136]. Chickens, for example, demonstrate no mortality following infection with WNV, yet titers as high as $5 \log _{10}$ $\mathrm{PFU} / \mathrm{mL}$ of serum have been identified and virus can be isolated from myocardium, spleen, kidney, lung, and intestine. Additionally, histopathological examination has identified myocardial necrosis, nephritis, and pneumonitis most notably in young birds [136].

The genetic changes observed in different WNV strains can modulate their virulence potential in avian species [23, 91]. Kunjin viruses have demonstrated low peak viremia thresholds compared to alternative lineage 1 WNV strains in both AMCR [23] and HOSP [91]. Other lineage $1 \mathrm{WNV}$, closely related to but different from the highly avian virulent NY99 WNV strain, have also demonstrated reduced viremia and subsequently lowered mortality rates in AMCR following experimental infection [77]. These data in accordance with the finding that WNV strains circulating in Israel that are genetically most similar to the NY99 strain have been associated with avian virulence [19] indicate that viral genetics play a crucial role in host susceptibility to lethal infection.

\subsubsection{Genotype associated with avian virulence}

Positive selection modeling of WNV representing members of all of the lineages has identified a single genetic loci (NS3-249) to be under adaptive evolution [24]. This residue lies within the helicase domain of the NS3 protein in an area not associated directly with RNA binding or ATP hydrolysis; however, incorporation of a NY99 substitution (NS3-T249P) into a closely related lineage $1 \mathrm{WNV}$ that elicited a low level of virulence in AMCR was sufficient to elicit a viremia and mortality response in crows indistinguishable from the NY99 strain. Interestingly, this avian virulence mutation, NS3-249P, has emerged on at least three independent occasions (Fig. 3). In each case, the viruses with this 


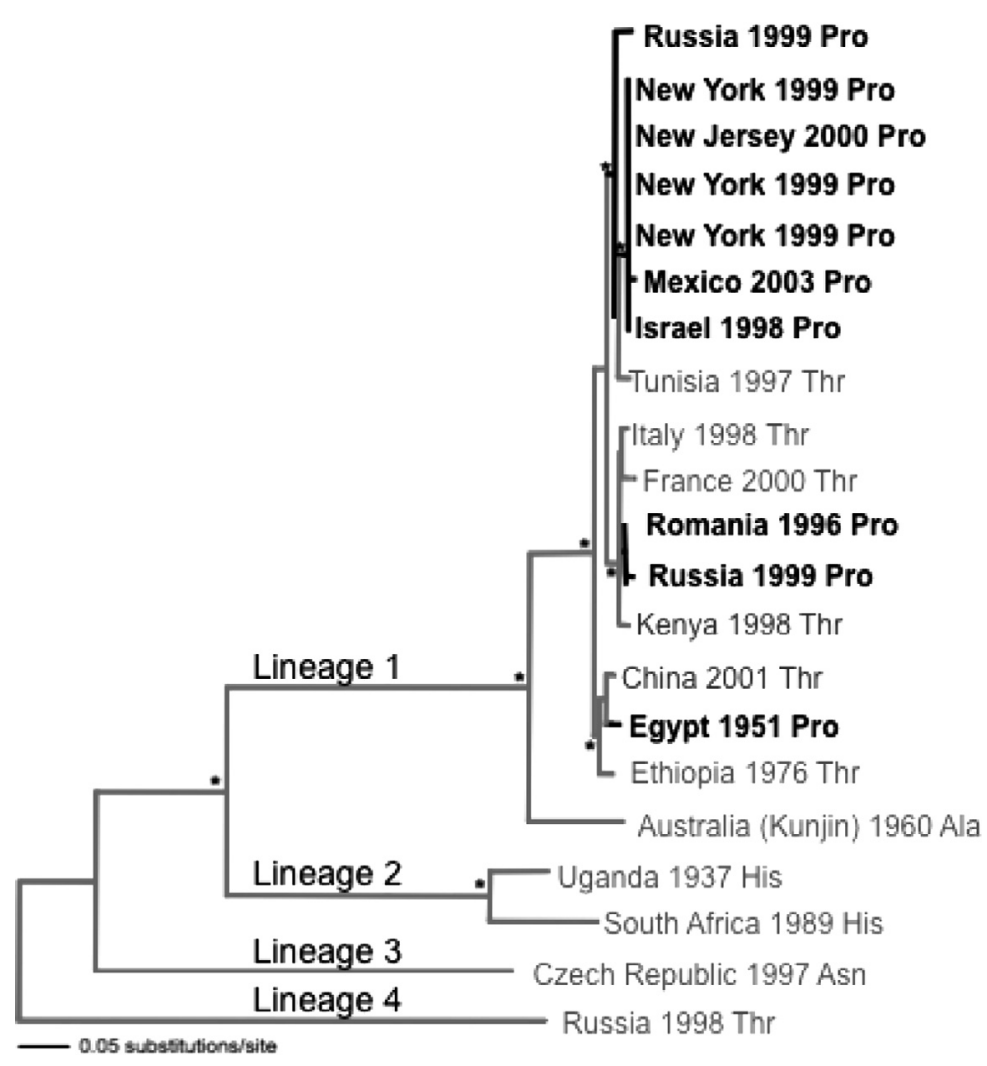

Figure 3. Maximum likelihood phylogenetic tree of 21 complete genomes of WNV. Viruses are grouped according to four described lineages of WNV (excluding the lineage 5 Indian group) and the genetic residue at each NS3-249 site is indicated. The three independent emergences of the NS3-249P genotype has been denoted on the tree. In each case an NS3-249Pro genotype emerged (designated in bold black) from a predecessor genotype (Thr; designated in grey). The asterisks represent nodes with bootstrap support values $>95 \%$.

substitution have been associated with human disease outbreaks; however, only the Egyptian 1951 isolate [164] as well as viruses from the Israeli/ North American clades [89] have been associated with avian virulence. The preponderance of these data indicated the potential importance of avian viremia for the emergence of lineage I WNV and suggests the potential for the emergence of alternative WNV genotypes following small genetic changes. Interestingly, several WNV lineages contain the NS3-249P substitution but have not been associated with avian virulence or the emergence of disease outbreaks indicating the possible limitations that particular WNV genetic backbones could impose on emergence potential of alternative genotypes as well as the potential role of the NS3-249P for increased replication in a wider array of avian species.

\subsubsection{Increased virulence as a factor for increased transmission}

A number of avian species are highly susceptible to WNV infection, exhibiting high 
viremias and associated mortality rates, and decreases in abundance [88]. Although it could be concluded that this resultant reduction of the breeding population would diminish transmission, high avian mortality is postulated to potentially increase transmission in three ways: (i) survival of previously infected and now immune birds could dilute the effect of subsequent transmission events [50], (ii) mortality in birds is associated with high peripheral viremia leading to the efficient infection of moderately susceptible mosquito vectors [23, 77, 83], and (iii) increased pathological manifestations could favor increased infection of mosquitoes due to reduced anti-mosquito defensive behavior of moribund avian hosts [33] as well as increased attractiveness to mosquitoes as a result of hyperthermia [77]. The time period in which avian hosts such as AMCR are the most viremic coincides with maximal viremia and moribund birds, presenting with elevated viremias on the ground could result in increased efficiency for infectivity of contact with vector mosquitoes, thereby increasing transmission potential of WNV to humans or equines [108]. Furthermore, it has been hypothesized that vector-borne agents have the potential for tolerance of higher levels of mortality. This has been theorized to result from the need for disseminated replication for the infection of arthropod vectors that often results in more serious clinical manifestations within the vertebrate host. The transmission of vector-borne viruses by mobile vectors has also been postulated to compensate for any dampening of transmission due to the lack of mobility of moribund vertebrate hosts [34, 43].

In contrast to WNV transmission in North America in which low oral infection rates of Culex spp. vectors are likely offset by high viremias in avian hosts, limited avian mortality and low oral infection thresholds of $C x$. univittatus and $C x$. tritaeniorhynchus vectors are transmission hallmarks within endemic foci. Although a few studies have demonstrated geographic differences in susceptibility of Old World endemic mosquito populations $[2,56]$, vector competence experiments with North American mosquitoes have indicated considerable temporal and spatial variability for oral susceptibility with no discernable pattern that could be linked to amplification [125]. These data taken together indicate the importance of avian amplification by invasive WNV for infection of marginally susceptible North American Culex spp. while low oral infection thresholds of specific vectors can allow for transmission in the absence of high avian viremias within endemic transmission. These differing evolutionary strategies are also evident with a closely related flavivirus, SLEV. Comparatively, despite the fact that they utilize the same avian hosts and mosquito vectors, SLEV has an approximately 10 -fold greater oral susceptibility than WNV but produces low magnitude viremias and is less virulent in birds [122].

\subsubsection{Viral adaptation for replication at higher temperature}

One factor that has classically defined the limit of the host range utilized by an RNA virus has been its ability to replicate at elevated temperature [36, 61]. Arboviruses such as WNV have a wide range of temperatures in which they must replicate in order to be propagated within both vertebrate and invertebrate hosts. An arbovirus such as dengue that replicates in primates is incapable of replicating at temperatures above $39^{\circ} \mathrm{C}$. This could be an important factor in the inability of these viruses to utilize birds (that have higher body temperatures) as vertebrate hosts [85]. Much of our knowledge in reference to replication at alternative temperatures is the result of the generation of temperature sensitive (ts) viral mutants for the identification of the functional role of viral proteins in the replication process [140] or the development of mutants that have impaired replication capacity [20, 167] for the development of vaccines. Replication of arboviruses in a two host system can moderate the amount of selection that can take place in either the vertebrate or invertebrate host [159]. Evidence also suggests that in vitro selection for increased replication in vertebrates can result in a decreased ability to replicate in mosquito tissues [54]. The temperature spectrum for which different arboviruses can replicate (and subsequently the hosts that they are capable of utilizing) is poorly understood. 
Previous studies have defined the potential importance of both temperature constraints within avian hosts [77] as well as mosquito vectors for WNV transmission. Degree-day models have identified the replication limit of WNV in mosquito vector to be constrained by temperatures below $14{ }^{\circ} \mathrm{C}$ and further demonstrated that the strain of WNV introduced to North American requires warmer temperatures for dissemination and subsequent transmission [124] than a WNV strains from sub-Saharan Africa [31]. Further data has demonstrated that the genotype of WNV that has predominated in North America since 2002, the WN02 genotype, seems to disseminate more rapidly and at a more efficient level at elevated temperatures than the prototype NY99 North American strain $[75,103]$. This shortening of the extrinsic incubation period (EIP), the time between a mosquito imbibing an infectious bloodmeal and being capable of transmitting virus by bite, could have been the factor by which this genotype of virus has been selected. Analyses of temperature patterns in the USA have demonstrated an association between above-normal temperatures and epidemics of WNV in northern latitudes [124]. These data coupled with the finding of increased efficiency of vector dissemination at elevated temperatures of the predominant WNV genotype indicate temperature as a potential important selection criterion for WNV evolution.

\subsection{Environmental factors associated with emergence}

\subsubsection{Climate perturbation}

Climate change can have a direct effect on WNV amplification rates in poikilothermic mosquito vectors as external temperature has been documented to have an inverse relationship to the duration of the EIP [124]. Additionally, increases in transmission season can result as well as expansion of transmission to more extreme latitudes and elevations. Although increasing temperature is negatively correlated with longevity of mosquitoes, in most instances the increased dissemination and transmission rates actually result in increased transmission efficiency. Patterns of WNV transmission are significantly linked to the abundance of vector populations. It has been determined that heavy rainfall in the spring and warm, dry temperatures during the summer are optimal for Culex spp. population increases and are positively correlated with WNV transmission $[120,126,137$, $138]$.

\subsubsection{Species diversity, species behavior and transmission dynamics}

One explanation for the lack of WNVassociated disease in Latin America is the increased avian species diversity in the tropics. It is hypothesized that increased species diversity could negatively impact transmission of WNV if there was a high proportion of incompetent hosts. One study has made such a connection by identifying a negative correlation between non-passerine species diversity and the force of WNV transmission, presumably owing to a dilution effect of vertebrate hosts with incompetent non-passerine avian species [44]. Other studies have suggested the importance of "super-spreaders" or certain avian species such as the American robin (Turdus migratorius) in temperate habitats that appear to not only be highly susceptible to infection with WNV but also are preferential sources for bloodmeals [73]. These concepts will require further investigation as a number of competing theories for the reduced impact of WNV in Latin America have been proposed including the circulation of WNV strains with reduced virulence phenotypes [15] and the potential inhibitory role of acquired immunity to heterologous flavivirus circulation in Mexico, Central and South America [47].

Shifts in mosquito host selection have been documented and associated with the potential for increased infection. One study indicated that Culex pipiens mosquitoes in the northeastern USA shift their feeding behavior from highly competent American robins to mammals and humans in the late summer to early fall, coinciding with the emigration of this avian species [74]. This host switching has also been observed with Culex tarsalis in the western USA [150] and $C x$. nigripalpus in Florida 
[38], indicating the importance of feeding behavior in the tangential transmission of WNV. Utilizing microsatellite markers to genetically distinguish Nearctic and Palearctic Culex spp. mosquitoes, one study inferred that Palearctic European species limit their feeding to avian hosts while North American Nearctic species feed indiscriminately upon avian and mammalian hosts [49] and concluded that this differential feeding behavior was the explanation for the lack of persistent WNV activity in Europe. However, a number of other studies [144] have provided evidence that Palearctic European Culex spp. feed on both mammalian and avian hosts, which contradicts the conclusion that feeding behavior could modulate epidemiological patterns.

Previously, WNV infection in AMCR has been uniformly lethal. However, the detection of seropositive AMCR has been reported, indicating that survival of individual birds in these highly susceptible avian species can occur [163]. Resistance to lethal infection could be associated with lower peak viremia, thus leading to selection for WNV genotypes with reduced oral infective thresholds for mosquitoes. As such, the effect that these modulations in vertebrate host population susceptibility could have on a concomitant selection for increased oral susceptibility of mosquito vectors should be monitored closely.

\subsubsection{Role of heterologous flaviviruses on WNV transmission}

The effect that the presence of heterologous flaviviruses has had on WNV transmission is a subject of some debate; however, it is apparent that increased avian herd immunity and mortality has had a detrimental effect on the transmission of, for instance, SLEV in southwestern transmission foci [127]. Cross-protection with WNV has been demonstrated to preclude House finches (HOFI) from mounting detectable viremia following SLEV challenge. Conversely, inoculation of HOFI with SLEV prior to $\mathrm{WNV}$ infection substantially reduces WNV viremia to levels below that associated with oral infection in most mosquito vectors [46, 123]. The potential effect of selective pressures from heterologous flaviviral immunity is currently not known. Heterologous infection of vertebrate hosts and mosquito vectors with alternative flaviviruses could also result in potential recombination events as well as block mosquito infectivity through barriers to super-infection. Barriers to super-infection have been described previously for arthropod-borne viruses [16, 32, 37, 41, 70, 141, 146]. For example, Aedes triseriatus mosquitoes experimentally infected with LaCrosse virus (LACV) have been shown to be resistant to infection with another closely related bunyavirus, Snowshoe Hare virus (SSHV), approximately two days post-infection [16]. A resistance period for dual infection was identified for ticks co-infected with Thogoto virus (THOV) for a period ranging between $24 \mathrm{~h}$ and 10 days of the initial infection with an alternative THOV strain [32]. An Aedes albopictus cell (C6/36) model further demonstrated that the inhibition of the secondarily infecting alphavirus is sequence specific. Alternative alphaviruses were blocked from super-infection of C6/36 cells, while unrelated bunyavirus or flaviviruses could establish infection in alphaviruses-infected $\mathrm{C} 6 / 36$ cells within the time period that these cells were resistant to infection with heterologous alphaviruses [37, 70]. The mechanism for this "super-infection exclusion" has not been identified; however, it has been hypothesized that competitive exclusion through template scavenging during RNA replication as well incompatible interactions between viral proteins exclude replication of the secondarily infecting virus. Inhibitory effects on the super-infecting virus have been identified in the processes of binding to the cellular surface receptors, low $\mathrm{pH}$ fusion with the endocytic vesicle, viral uncoating, viral replication as well as viral maturation and budding [141].

\subsubsection{Alternation of transmission patterns}

Since WNV was introduced into the USA in 1999, an identified pattern has been recognized in which the season of introduction is characterized by mild activity with few human cases. This is followed by an epidemic year characterized by large numbers of cases, high infection 
rates in mosquitoes with subsequent avian seroconversions and mortality. The third season of activity has been referred to as the "subsidence year" in which human cases and enzootic indicators drop precipitously, presumably owing to increased herd immunity and avian depopulation of highly competent amplification hosts [119]. Decreased avian herd immunity resulting from the presence of naïve hatchlings as well as waning immunity in after-hatch year birds is then conducive for continued transmission during subsequent seasons. In contrast, areas lacking "super spreaders" or highly susceptible corvids have failed to amplify enzootic transmission to outbreak levels [127], whereas other areas have experienced recurring epidemic level transmission during sequential seasons [128]. The identification of more severe neurological syndromes in North America could be the result of an increased virulence of the WNV strain introduced as well as age-related exposure rates in a completely naïve population. Within endemic areas of WNV or SLEV transmission in which youth exposure rates are high, neuroinvasive disease is uncommon. While the virulence of the imported strains deserves further attention, the role of a "virgin soil" effect should not be overlooked as an explanation for the altered disease phenotypes observed in North America.

\section{CONCLUSION}

Since its introduction to North America, WNV has undergone a dramatic increase in geographic range and has demonstrated a greater association with a more severe neurological clinical presentation. Undoubtedly a number of ecological, virological and social factors have contributed to this emergence. Virological factors highlighted in this review have included genetic adaptation for increased replication in avian hosts as well as increased dissemination in mosquito vectors at elevated temperatures. As with other RNA viruses, the presence of an error-prone polymerase that lacks proofreading function coupled with the large population sizes occurring in both infected avian hosts and mosquito vectors allow for the rapid selection of novel genotypes. Novel ecological niches that have been created by climatic perturbations and social or demographic changes assuredly will result in the emergence of novel genotypes to occupy these habitats and thus perpetuate the continually changing landscape of WNV epidemiology.

Acknowledgements. I would like to thank Dr Eddie Holmes for the construction of the Phylogenetic tree presented in Figure 3 as well as Dr Bill Reisen for his many helpful suggestions.

\section{REFERENCES}

[1] Adams S.C., Broom A.K., Sammels L.M., Hartnett A.C., Howard M.J., Coelen R.J., et al., Glycosylation and antigenic variation among Kunjin virus isolates, Virology (1995) 206:49-56.

[2] Ahmed T., Hayes C.G., Baqar S., Comparison of vector competence for West Nile virus of colonized populations of Culex tritaeniorhynchus from southern Asia and the Far East, Southeast Asian J. Trop. Med. Public Health (1979) 10:498-504.

[3] Akhter R., Hayes C.G., Baqar S., Reisen W.K., West Nile virus in Pakistan III. Comparative vector capability of Culex tritaeniorhynchus and eight other species of mosquitoes, Trans. R. Soc. Trop. Med. Hyg. (1982) 76:449-453.

[4] Anonymous, Outbreak of West Nile-like viral encephalitis - New York, 1999, MMWR Morb. Mortal. Wkly Rep. (1999) 48:845-849.

[5] Anonymous, Update: West Nile-like viral encephalitis - New York, 1999, MMWR Morb. Mortal. Wkly Rep. (1999) 48:890-892.

[6] Anonymous, Human West Nile virus surveillance - Connecticut, New Jersey, and New York, 2000, MMWR Morb. Mortal. Wkly Rep. (2001) 50:265268.

[7] Anonymous, West Nile virus infection may be greater than previously thought, FDA Consum. (2001) 35:38.

[8] Anonymous, Acute flaccid paralysis syndrome associated with West Nile virus infection - Mississippi and Louisiana, July-August 2002, MMWR Morb. Mortal. Wkly Rep. (2002) 51:825-828.

[9] Austgen L.E., Bowen R.A., Bunning M.L., Davis B.S., Mitchell C.J., Chang G.J., Experimental infection of cats and dogs with West Nile virus, Emerg. Infect. Dis. (2004) 10:82-86. 
[10] Autorino G.L., Battisti A., Deubel V., Ferrari G., Forletta R., Giovannini A., et al., West Nile virus epidemic in horses, Tuscany region, Italy, Emerg. Infect. Dis. (2002) 8:1372-1378.

[11] Bakonyi T., Hubalek Z., Rudolf I., Nowotny N., Novel flavivirus or new lineage of West Nile virus central Europe, Emerg. Infect. Dis. (2005) 11:225-231.

[12] Beasley D.W., Li L., Suderman M.T., Barrett A.D., West Nile virus strains differ in mouse neurovirulence and binding to mouse or human brain membrane receptor preparations, Ann. N.Y. Acad. Sci. (2001) 951:332-335.

[13] Beasley D.W., Li L., Suderman M.T., Barrett A.D., Mouse neuroinvasive phenotype of West Nile virus strains varies depending upon virus genotype, Virology (2002) 296:17-23.

[14] Beasley D.W., Davis C.T., Guzman H., Vanlandingham D.L., Travassos da Rosa A.P., Parsons R.E., et al., Limited evolution of West Nile virus has occurred during its southwesterly spread in the United States, Virology (2003) 309:190-195.

[15] Beasley D.W., Davis C.T., Estrada-Franco J., Navarro-Lopez R., Campomanes-Cortes A., Tesh R.B., et al., Genome sequence and attenuating mutations in West Nile virus isolate from Mexico, Emerg. Infect. Dis. (2004) 10:2221-2224.

[16] Beaty B.J., Sundin D.R., Chandler L.J., Bishop D.H., Evolution of bunyaviruses by genome reassortment in dually infected mosquitoes (Aedes triseriatus), Science (1985) 230:548-550.

[17] Bernard K.A., Maffei J.G., Jones S.A., Kauffman E.B., Ebel G., Dupuis A.P. 2nd, et al., West Nile virus infection in birds and mosquitoes, New York State, 2000, Emerg. Infect. Dis. (2001) 7:679-685.

[18] Berthet F.X., Zeller H.G., Drouet M.T., Rauzier J., Digoutte J.P., Deubel V., Extensive nucleotide changes and deletions within the envelope glycoprotein gene of Euro-African West Nile viruses, J. Gen. Virol. (1997) 78:2293-2297.

[19] Bin H., Grossman Z., Pokamunski S., Malkinson M., Weiss L., Duvdevani P., et al., West Nile fever in Israel 1999-2000: from geese to humans, Ann. N.Y. Acad. Sci. (2001) 951:127-142.

[20] Blaney J.E. Jr., Manipon G.G., Murphy B.R., Whitehead S.S., Temperature sensitive mutations in the genes encoding the NS1, NS2A, NS3, and NS5 nonstructural proteins of dengue virus type 4 restrict replication in the brains of mice, Arch. Virol. (2003) 148:999-1006.

[21] Bondre V.P., Jadi R.S., Mishra A.C., Yergolkar P.N., Arankalle V.A., West Nile virus isolates from
India: evidence for a distinct genetic lineage, J. Gen. Virol. (2007) 88:875-884.

[22] Boyle D.B., Marshall I.D., Dickerman R.W., Primary antibody responses of herons to experimental infection with Murray Valley encephalitis and Kunjin viruses, Aust. J. Exp. Biol. Med. Sci. (1983) 61:665674.

[23] Brault A.C., Langevin S.A., Bowen R.A., Panella N.A., Biggerstaff B.J., Miller B.R., Komar $\mathrm{N}$., Differential virulence of West Nile strains for American crows, Emerg. Infect. Dis. (2004) 10:21612168.

[24] Brault A.C., Huang C.Y., Langevin S.A., Kinney R.M., Bowen R.A., Ramey W.N., et al., A single positively selected West Nile viral mutation confers increased virogenesis in American crows, Nat. Genet. (2007) 39:1162-1166.

[25] Brinton M.A., Dispoto J.H., Sequence and secondary structure analysis of the $5^{\prime}$-terminal region of flavivirus genome RNA, Virology (1988) 162:290 299.

[26] Bunning M.L., Bowen R.A., Cropp B., Sullivan K., Davis B., Komar N., et al., Experimental infection of horses with West Nile virus and their potential to infect mosquitoes and serve as amplifying hosts, Ann. N.Y. Acad. Sci. (2001) 951:338-339.

[27] Calisher C.H., Karabatsos N., Dalrymple J.M., Shope R.E., Porterfield J.S., Westaway E.G., Brandt W.E., Antigenic relationships between flaviviruses as determined by cross-neutralization tests with polyclonal antisera, J. Gen. Virol. (1989) 70:37-43.

[28] Ceausu E., Erscoiu S., Calistru P., Ispas D., Dorobat O., Homos M., et al., Clinical manifestations in the West Nile virus outbreak, Rom. J. Virol. (1997) 48:3-11.

[29] Charrel R.N., Brault A.C., Gallian P., Lemasson J.J., Murgue B., Murri S., et al., Evolutionary relationship between Old World West Nile virus strains. Evidence for viral gene flow between Africa, the Middle East, and Europe, Virology (2003) 315:381-388.

[30] Chowers M.Y., Lang R., Nassar F., Ben-David D., Giladi M., Rubinshtein E., et al., Clinical characteristics of the West Nile fever outbreak, Israel, 2000, Emerg. Infect. Dis. (2001) 7:675-678.

[31] Cornel A.J., Jupp P.G., Blackburn N.K., Environmental temperature on the vector competence of Culex univittatus (Diptera: Culicidae) for West Nile virus, J. Med. Entomol. (1993) 30:449-456.

[32] Davies C.R., Jones L.D., Nuttall P.A., Viral interference in the tick, Rhipicephalus appendiculatus. 
I. Interference to oral superinfection by Thogoto virus, J. Gen. Virol. (1989) 70:2461-2468.

[33] Day J.F., Edman J.D., Malaria renders mice susceptible to mosquito feeding when gametocytes are most infective, J. Parasitol. (1983) 69:163-170.

[34] Day T., Parasite transmission modes and the evolution of virulence, Evolution (2001) 55:23892400 .

[35] Dunkel B., Del Piero F., Wotman K.L., Johns I.C., Beech J., Wilkins P.A., Encephalomyelitis from West Nile flavivirus in 3 alpacas, J. Vet. Intern. Med. (2004) 18:365-367.

[36] Dunster L.M., Gibson C.A., Stephenson J.R., Minor P.D., Barrett A.D., Attenuation of virulence of flaviviruses following passage in HeLa cells, J. Gen. Virol. (1990) 71:601-607.

[37] Eaton B.T., Heterologous interference in Aedes albopictus cells infected with alphaviruses, J. Virol. (1979) 30:45-55.

[38] Edman J.D., Taylor D.J., Culex nigripalpus: seasonal shift in the bird-mammal feeding ratio in a mosquito vector of human encephalitis, Science (1968) 161:67-68.

[39] Eidson M., Komar N., Sorhage F., Nelson R., Talbot T., Mostashari F., McLean R., Crow deaths as a sentinel surveillance system for West Nile virus in the northeastern United States, 1999, Emerg. Infect. Dis. (2001) 7:615-620.

[40] Eidson M., Kramer L., Stone W., Hagiwara Y., Schmit K., Dead bird surveillance as an early warning system for West Nile virus, Emerg. Infect. Dis. (2001) 7:631-635.

[41] el Hussein A., Ramig R.F., Holbrook F.R., Beaty B.J., Asynchronous mixed infection of Culicoides variipennis with bluetongue virus serotypes 10 and 17 , J. Gen. Virol. (1989) 70:3355-3362.

[42] Eldadah A.H., Nathanson N., Sarsitis R., Pathogenesis of West Nile virus encephalitis in mice and rats. 1. Influence of age and species on mortality and infection, Am. J. Epidemiol. (1967) 86:765-775.

[43] Ewald P.W., The evolution of virulence and emerging diseases, J. Urban Health (1998) 75:480-491.

[44] Ezenwa V.O., Godsey M.S., King R.J., Guptill S.C., Avian diversity and West Nile virus: testing associations between biodiversity and infectious disease risk, Proc. Biol. Sci. (2006) 273:109-117.

[45] Fagbami A., Human arthropod-borne virus infections in Nigeria. Serological and virological investigations and Shaki, Oyo State, J. Hyg. Epidemiol. Microbiol. Immunol. (1978) 22:184-189.
[46] Fang Y., Reisen W.K., Previous infection with West Nile or St. Louis encephalitis viruses provides cross protection during reinfection in house finches, Am. J. Trop. Med. Hyg. (2006) 75:480-485.

[47] Farfan-Ale J.A., Lorono-Pino M.A., GarciaRejon J.E., Hovav E., Powers A.M., Lin M., et al., Detection of RNA from a Novel West Nile-like virus and high prevalence of an insect-specific flavivirus in mosquitoes in the Yucatan Peninsula of Mexico, Am. J. Trop. Med. Hyg. (2009) 80:85-95.

[48] Fitzgeorge R., Bradish C.J., The in vivo differentiation of strains of yellow fever virus in mice, $\mathrm{J}$. Gen. Virol. (1980) 46:1-13.

[49] Fonseca D.M., Keyghobadi N., Malcolm C.A., Mehmet C., Schaffner F., Mogi M., et al., Emerging vectors in the Culex pipiens complex, Science (2004) 303:1535-1538.

[50] Foppa I.M., Spielman A., Does reservoir host mortality enhance transmission of West Nile virus?, Theor. Biol. Med. Model. (2007) 4:17.

[51] Gomez A., Kramer L.D., Dupuis A.P. 2nd, Kilpatrick A.M., Davis L.J., Jones M.J., et al., Experimental infection of eastern gray squirrels (Sciurus carolinensis) with West Nile virus, Am. J. Trop. Med. Hyg. (2008) 79:447-451.

[52] Halevy M., Akov Y., Ben-Nathan D., Kobiler D., Lachmi B., Lustig S., Loss of active neuroinvasiveness in attenuated strains of West Nile virus: pathogenicity in immunocompetent and SCID mice, Arch. Virol. (1994) 137:355-370.

[53] Hall R.A., Broom A.K., Smith D.W., Mackenzie J.S., The ecology and epidemiology of Kunjin virus, Curr. Top. Microbiol. Immunol. (2002) 267:253-269.

[54] Hanley K.A., Manlucu L.R., Gilmore L.E., Blaney J.E. Jr., Hanson C.T., Murphy B.R., et al., A trade-off in replication in mosquito versus mammalian systems conferred by a point mutation in the NS4B protein of dengue virus type 4, Virology (2003) 312:222-232.

[55] Hayes C.G., Baqar S., Ahmed T., Chowdhry M.A., Reisen W.K., West Nile virus in Pakistan. 1. Sero-epidemiological studies in Punjab Province, Trans. R. Soc. Trop. Med. Hyg. (1982) 76:431-436.

[56] Hayes C.G., Baker R.H., Baqar S., Ahmed T., Genetic variation for West Nile virus susceptibility in Culex tritaeniorhynchus, Am. J. Trop. Med. Hyg. (1984) 33:715-724.

[57] Hayes C.G., West Nile Fever, in: Monath T.P. (Ed.), The Arboviruses: epidemiology and ecology, CRC Press, Boca Raton, FL, 1988, pp. 59-88. 
[58] Hayes E.B., Virology, pathology, and clinical manifestations of West Nile virus disease, Emerg. Infect. Dis. (2005) 11:1174-1179.

[59] Heinz F., Collet M., Purcell R., Gould E., Howeard C., Houghton M., Family Flaviviridae, in: Van Regenmortel M. (Ed.), Virus taxonomy: classification and nomenclature of viruses, Academic Press, San Diego, 2000, pp. 859-878.

[60] Heinz-Taheny K.M., Andrews J.J., Kinsel M.J., Pessier A.P., Pinkerton M.E., Lemberger K.Y., et al., West Nile virus infection in free-ranging squirrels in Illinois, J. Vet. Diagn. Invest. (2004) 16:186-190.

[61] Huang C.Y., Butrapet S., Pierro D.J., Chang G.J., Hunt A.R., Bhamarapravati N., et al., Chimeric dengue type 2 (vaccine strain PDK-53)/dengue type 1 virus as a potential candidate dengue type 1 virus vaccine, J. Virol. (2000) 74:3020-3028.

[62] Jacobson E.R., Ginn P.E., Troutman J.M., Farina L., Stark L., Klenk K., et al., West Nile virus infection in farmed American alligators (Alligator mississippiensis) in Florida, J. Wildl. Dis. (2005) 41:96-106.

[63] Jia X.Y., Briese T., Jordan I., Rambaut A., Chi H.C., Mackenzie J.S., et al., Genetic analysis of West Nile New York 1999 encephalitis virus, Lancet (1999) 354:1971-1972.

[64] Joubert L., Oudar J., Hannoun C., Beytout D., Corniou B., Guillon J.C., et al., Epidemiology of the West Nile virus: study of a focus in Camargue. IV. Meningo-encephalomyelitis of the horse, Ann. Inst. Pasteur (Paris) (1970) 118:239-247 (in French).

[65] Julian K.G., Eidson M., Kipp A.M., Weiss E., Petersen L.R., Miller J.R., et al., Early season crow mortality as a sentinel for West Nile virus disease in humans, northeastern United States, Vector Borne Zoonotic Dis. (2002) 2:145-155.

[66] Jupp P.G., Laboratory studies on the transmission of West Nile virus by Culex (Culex) univittatus) Theobald; factors influencing the transmission rate, J. Med. Entomol. (1974) 11:455-458.

[67] Jupp P.G., Laboratory studies on the vector capability of Aedes (neomelaniconion) unidentatus McIntosh and Aedes (Aedimorphus dentatus Theobald) with West Nile and Sindbis viruses, S. Afr. J. Med. Sci. (1976) 41:265-269.

[68] Jupp P.G., The ecology of West Nile virus in South Africa and the occurrence of outbreaks in humans, Ann. N.Y. Acad. Sci. (2001) 951:143-152.

[69] Kanamitsu M., Taniguchi K., Urasawa S., Ogata T., Wada Y., Saroso J.S., Geographic distribution of arbovirus antibodies in indigenous human populations in the Indo-Australian archipelago, Am. J. Trop. Med. Hyg. (1979) 28:351-363.
[70] Karpf A.R., Lenches E., Strauss E.G., Strauss J.H., Brown D.T., Superinfection exclusion of alphaviruses in three mosquito cell lines persistently infected with Sindbis virus, J. Virol. (1997) 71: 7119-7123.

[71] Kecskemeti S., Bajmocy E., Bacsadi A., Kiss I., Bakonyi T., Encephalitis due to West Nile virus in a sheep, Vet. Rec. (2007) 161:568-569.

[72] Khromykh A.A., Meka H., Guyatt K.J., Westaway E.G., Essential role of cyclization sequences in flavivirus RNA replication, J. Virol. (2001) 75:67196728.

[73] Kilpatrick A.M., Daszak P., Jones M.J., Marra P.P., Kramer L.D., Host heterogeneity dominates West Nile virus transmission, Proc. Biol. Sci. (2006) 273: 2327-2333.

[74] Kilpatrick A.M., Kramer L.D., Jones M.J., Marra P.P., Daszak P., West Nile virus epidemics in North America are driven by shifts in mosquito feeding behavior, PLoS Biol. (2006) 4:e82.

[75] Kilpatrick A.M., Meola M.A., Moudy R.M., Kramer L.D., Temperature, viral genetics, and the transmission of West Nile virus by Culex pipiens mosquitoes, PLoS Pathog. (2008) 4:e1000092.

[76] Kimura T., Ohyama A., Association between the $\mathrm{pH}$-dependent conformational change of West Nile flavivirus $\mathrm{E}$ protein and virus-mediated membrane fusion, J. Gen. Virol. (1988) 69:1247-1254.

[77] Kinney R.M., Huang C.Y., Whiteman M.C., Bowen R.A., Langevin S.A., Miller B.R., Brault A.C., Avian virulence and thermostable replication of the North American strain of West Nile virus, J. Gen. Virol. (2006) 87:3611-3622.

[78] Kiupel M., Simmons H.A., Fitzgerald S.D., Wise A., Sikarskie J.G., Cooley T.M., et al., West Nile virus infection in Eastern fox squirrels (Sciurus niger), Vet. Pathol. (2003) 40:703-707.

[79] Klenk K., Snow J., Morgan K., Bowen R., Stephens M., Foster F., et al., Alligators as West Nile virus amplifiers, Emerg. Infect. Dis. (2004) 10:21502155 .

[80] Kolman J.M., Serologic examination of some domestic animals from South Moravia on the presence of antibodies to selected arboviruses of the A, B, California and Bunyamwera groups, Folia Parasitol. (1973) 20:353-360.

[81] Kolman J.M., Folk C., Hudec K., Reddy G.N., Serologic examination of birds from the area of southern Moravia for the presence of antibodies against arboviruses of the groups Alfa, Flavo, Uukuniemi, Turlock and Bunyamwera supergroup. II. Wild living birds, Folia Parasitol. (1976) 23:251-255. 
[82] Komar N., Panella N.A., Burns J.E., Dusza S.W., Mascarenhas T.M., Talbot T.O., Serologic evidence for West Nile virus infection in birds in the New York City vicinity during an outbreak in 1999, Emerg. Infect. Dis. (2001) 7:621-625.

[83] Komar N., Langevin S., Hinten S., Nemeth N., Edwards E., Hettler D., et al., Experimental infection of North American birds with the New York 1999 strain of West Nile virus, Emerg. Infect. Dis. (2003) 9:311-322.

[84] Krisztalovics K., Ferenczi E., Molnar Z., Csohan A., Ban E., Zoldi V., Kaszas K., West Nile virus infections in Hungary, August-September 2008, Euro Surveill. (2008) 13:19030.

[85] Kuno G., Factors influencing the transmission of dengue viruses, in: Gubler D.J., Kuno G. (Eds.), Dengue and dengue hemorrhagic Fever, CAB International, New York, 1997, pp. 61-88.

[86] Kutzler M.A., Baker R.J., Mattson D.E., Humoral response to West Nile virus vaccination in alpacas and llamas, J. Am. Vet. Med. Assoc. (2004) 225:414-416.

[87] Kutzler M.A., Bildfell R.J., Gardner-Graff K.K., Baker R.J., Delay J.P., Mattson D.E., West Nile virus infection in two alpacas, J. Am. Vet. Med. Assoc. (2004) 225:921-924, 880.

[88] Ladeau S.L., Kilpatrick A.M., Marra P.P., West Nile virus emergence and large-scale declines of North American bird populations, Nature (2007) 447:710 713.

[89] Lanciotti R.S., Roehrig J.T., Deubel V., Smith J., Parker M., Steele K., et al., Origin of the West Nile virus responsible for an outbreak of encephalitis in the northeastern United States, Science (1999) 286:23332337.

[90] Lanciotti R.S., Ebel G.D., Deubel V., Kerst A.J., Murri S., Meyer R., et al., Complete genome sequences and phylogenetic analysis of West Nile virus strains isolated from the United States, Europe, and the Middle East, Virology (2002) 298:96-105.

[91] Langevin S.A., Brault A.C., Panella N.A., Bowen R.A., Komar N., Variation in virulence of West Nile virus strains for house sparrows (Passer domesticus), Am. J. Trop. Med. Hyg. (2005) 72:99102 .

[92] Lvov D.K., Butenko A.M., Gromashevsky V.L., Kovtunov A.I., Prilipov A.G., Kinney R., et al., West Nile virus and other zoonotic viruses in Russia: examples of emerging-reemerging situations, Arch. Virol. Suppl. (2004) 85-96.

[93] Macini P., Squintani G., Finarelli A.C., Angelini P., Martini E., Tamba M., et al., Detection of West Nile virus infection in horses, Italy, September 2008, Euro Surveill. (2008) 13:18990.

[94] Mackenzie J.S., Barrett A.D., Deubel V., The Japanese encephalitis serological group of flaviviruses: a brief introduction to the group, Curr. Top. Microbiol. Immunol. (2002) 267:1-10.

[95] Malkinson M., Banet C., Weisman J., Prokamonski S., King R., West Nile fever: recent evidence for the intercontinental dispersion of the virus by migratory birds, Proceedings of the 11th International Congress of Virology, Sydney, Australia, International Union of Microbiological Societies, 1999.

[96] Malkinson M., Banet C., Khinich Y., Samina I., Pokamunski S., Weisman Y., Use of live and inactivated vaccines in the control of West Nile fever in domestic geese, Ann. N.Y. Acad. Sci. (2001) 951:255261 .

[97] Malkinson M., Weisman Y., Pokamonski S., King R., Deubel V., Intercontinental transmission of West Nile virus by migrating white storks, Emerg. Infect. Dis. (2001) 7:540.

[98] Marfin A.A., Gubler D.J., West Nile encephalitis: an emerging disease in the United States, Clin. Infect. Dis. (2001) 33:1713-1719.

[99] Mashimo T., Lucas M., Simon-Chazottes D., Frenkiel M.P., Montagutelli X., Ceccaldi P.E., et al., A nonsense mutation in the gene encoding $2^{\prime}-5^{\prime}$-oligoadenylate synthetase/L1 isoform is associated with West Nile virus susceptibility in laboratory mice, Proc. Natl. Acad. Sci. USA (2002) 99:11311-11316.

[100] McIntosh B.M., Dickinson D.B., McGillivray G.M., Ecological studies on Sindbis and West Nile viruses in South Africa. V. The response of birds to inoculation of virus, S. Afr. J. Med. Sci. (1969) 34: 77-82.

[101] Miller B.R., Nasci R.S., Godsey M.S., Savage H.M., Lutwama J.J., Lanciotti R.S., Peters C.J., First field evidence for natural vertical transmission of West Nile virus in Culex univittatus complex mosquitoes from Rift Valley province, Kenya, Am. J. Trop. Med. Hyg. (2000) 62:240-246.

[102] Mishra A.C., Mourya D.T., Transovarial transmission of West Nile virus in Culex vishnui mosquito, Indian J. Med. Res. (2001) 114:212-214.

[103] Moudy R.M., Meola M.A., Morin L.L., Ebel G.D., Kramer L.D., A newly emergent genotype of West Nile virus is transmitted earlier and more efficiently by culex mosquitoes, Am. J. Trop. Med. Hyg. (2007) 77:365-370.

[104] Murgue B., Murri S., Triki H., Deubel V., Zeller H.G., West Nile in the Mediterranean basin: 1950 2000, Ann. N.Y. Acad. Sci. (2001) 951:117-126. 
[105] Murgue B., Zeller H., Deubel V., The ecology and epidemiology of West Nile virus in Africa Europe and Asia, Curr. Top. Microbiol. Immunol. (2002) 267:195-221

[106] Nash D., Mostashari F., Fine A., Miller J., O'Leary D., Murray K., et al., The outbreak of West Nile virus infection in the New York City area in 1999, N. Engl. J. Med. (2001) 344:1807-1814.

[107] Ni H., Ryman K.D., Wang H., Saeed M.F., Hull R., Wood D., et al., Interaction of yellow fever virus French neurotropic vaccine strain with monkey brain: characterization of monkey brain membrane receptor escape variants, J. Virol. (2000) 74:2903-2906.

[108] Nielsen C.F., Reisen W.K., West Nile virusinfected dead corvids increase the risk of infection in Culex mosquitoes (Diptera: Culicidae) in domestic landscapes, J. Med. Entomol. (2007) 44:1067-1073.

[109] Nir Y., Goldwasser R., Lasowski Y., Margalit J., Isolation of West Nile virus strains from mosquitoes in Israel, Am. J. Epidemiol. (1968) 87:496-501.

[110] Odelola H.A., Oduye O.O., West Nile virus infection of adult mice by oral route, Arch. Virol. (1977) 54:251-253.

[111] Padgett K.A., Reisen W.K., Kahl-Purcell N., Fang Y., Cahoon-Young B., Carney R., et al., West Nile virus infection in tree squirrels (Rodentia: Sciuridae) in California, 2004-2005, Am. J. Trop. Med. Hyg. (2007) 76:810-813.

[112] Platt K.B., Tucker B.J., Halbur P.G., Tiawsirisup S., Blitvich B.J., Fabiosa F.G., et al., West Nile virus viremia in eastern chipmunks (Tamias striatus) sufficient for infecting different mosquitoes, Emerg. Infect. Dis. (2007) 13:831-837.

[113] Platt K.B., Tucker B.J., Halbur P.G., Blitvich B.J., Fabiosa F.G., Mullin K., et al., Fox squirrels (Sciurus niger) develop West Nile virus viremias sufficient for infecting select mosquito species, Vector Borne Zoonotic Dis. (2008) 8:225-233.

[114] Pogodina V.V., Frolova M.P., Malenko G.V., Fokina G.I., Koreshkova G.V., Kiseleva L.L., et al., Study on West Nile virus persistence in monkeys, Arch. Virol. (1983) 75:71-86.

[115] Poidinger M., Hall R.A., Mackenzie J.S., Molecular characterization of the Japanese encephalitis serocomplex of the flavivirus genus, Virology (1996) 218:417-421.

[116] Popovici F., Sarbu A., Nicolae O., Pistol A., Cucuiu R., Stolica B., et al., West Nile fever in a patient in Romania, August 2008: case report, Euro Surveill. (2008) 13:18989.
[117] Prilipov A.G., Kinney R.M., Samokhvalov E.I., Savage H.M., Al'khovskii S.V., Tsuchiya K.R., et al., Analysis of new variants of West Nile fever virus, Vopr. Virusol. (2002) 47:36-41 (in Russian).

[118] Rappole J.H., Compton B.W., Leimgruber P., Robertson J., King D.I., Renner S.C., Modeling movement of West Nile virus in the Western hemisphere, Vector Borne Zoonotic Dis. (2006) 6:128-139.

[119] Reisen W., Lothrop H., Chiles R., Madon M., Cossen C., Woods L., et al., West Nile virus in California, Emerg. Infect. Dis. (2004) 10:1369-1378.

[120] Reisen W., Brault A.C., West Nile virus in North America: perspectives on epidemiology and intervention, Pest. Manage. Sci. (2007) 63:641-646.

[121] Reisen W.K., Hayes C.G., Azra K., Niaz S., Mahmood F., Parveen T., et al., West Nile virus in Pakistan, II. Entomological studies at Changa Manga National Forest, Punjab Province, Trans. R. Soc. Trop. Med. Hyg. (1982) 76:437-448.

[122] Reisen W.K., Chiles R.E., Martinez V.M., Fang Y., Green E.N., Experimental infection of California birds with western equine encephalomyelitis and St. Louis encephalitis viruses, J. Med. Entomol. (2003) 40:968-982.

[123] Reisen W.K., Fang Y., Martinez V.M., Avian host and mosquito (Diptera: Culicidae) vector competence determine the efficiency of West Nile and St. Louis encephalitis virus transmission, J. Med. Entomol. (2005) 42:367-375.

[124] Reisen W.K., Fang Y., Martinez V.M., Effects of temperature on the transmission of West Nile virus by Culex tarsalis (Diptera: Culicidae), J. Med. Entomol. (2006) 43:309-317.

[125] Reisen W.K., Barker C.M., Fang Y., Martinez V.M., Does variation in Culex (Diptera: Culicidae) vector competence enable outbreaks of West Nile virus in California?, J. Med. Entomol. (2008) 45:1126-1138.

[126] Reisen W.K., Cayan D., Tyree M., Barker C.M., Eldridge B., Dettinger M., Impact of climate variation on mosquito abundance in California, $\mathrm{J}$. Vector Ecol. (2008) 33:89-98.

[127] Reisen W.K., Lothrop H.D., Wheeler S.S., Kennsington M., Gutierrez A., Fang Y., et al., Persistent West Nile virus transmission and the apparent displacement St. Louis encephalitis virus in southeastern California, 2003-2006, J. Med. Entomol. (2008) 45:494-508.

[128] Reisen W.K., Carroll B.D., Takahashi R., Fang Y., Garcia S., Martinez V.M., Quiring R., Repeated West Nile virus epidemic transmission in Kern County, California, 2004-2007, J. Med. Entomol. (2009) 46:139-157. 
[129] Rice C.M., Flaviviridae: the viruses and their replication, in: Fields B.N., Knipe D.M., Howley P.M. (Eds.), Fields virology, Lippincott-Raven, Philadelphia, PA, 1996, pp. 931-959.

[130] Roehrig J.T., Staudinger L.A., Hunt A.R., Mathews J.H., Blair C.D., Antibody prophylaxis and therapy for flavivirus encephalitis infections, Ann. N.Y. Acad. Sci. (2001) 951:286-297.

[131] Roehrig J.T., Layton M., Smith P., Campbell G.L., Nasci R., Lanciotti R.S., The emergence of West Nile virus in North America: ecology, epidemiology, and surveillance, Curr. Top. Microbiol. Immunol. (2002) 267:223-240.

[132] Root J.J., Oesterle P.T., Nemeth N.M., Klenk K., Gould D.H., McLean R.G., et al., Experimental infection of fox squirrels (Sciurus niger) with West Nile virus, Am. J. Trop. Med. Hyg. (2006) 75:697701.

[133] Rossini G., Cavrini F., Pierro A., Macini P., Finarelli A., Po C., et al., First human case of West Nile virus neuroinvasive infection in Italy, September 2008 - case report, Euro Surveill. (2008) 13:19002.

[134] Savage H.M., Ceianu C., Nicolescu G., Karabatsos N., Lanciotti R., Vladimirescu A., et al., Entomologic and avian investigations of an epidemic of West Nile fever in Romania in 1996, with serologic and molecular characterization of a virus isolate from mosquitoes, Am. J. Trop. Med. Hyg. (1999) 61: 600-611.

[135] Scherret J.H., Poidinger M., Mackenzie J.S., Broom A.K., Deubel V., Lipkin W.I., et al., The relationships between West Nile and Kunjin viruses, Emerg. Infect. Dis. (2001) 7:697-705.

[136] Senne D.A., Pedersen J.C., Hutto D.L., Taylor W.D., Schmitt B.J., Panigrahy B., Pathogenicity of West Nile virus in chickens, Avian Dis. (2000) 44:642-649.

[137] Shaman J., Day J.F., Stieglitz M., The spatialtemporal distribution of drought, wetting, and human cases of St. Louis encephalitis in southcentral Florida, Am. J. Trop. Med. Hyg. (2004) 71:251-261.

[138] Shaman J., Day J.F., Stieglitz M., Droughtinduced amplification and epidemic transmission of West Nile virus in southern Florida, J. Med. Entomol. (2005) 42:134-141.

[139] Shi P.Y., Brinton M.A., Veal J.M., Zhong Y.Y., Wilson W.D., Evidence for the existence of a pseudoknot structure at the $3^{\prime}$ terminus of the flavivirus genomic RNA, Biochemistry (1996) 35:4222-4230.

[140] Shirako Y., Strauss J.H., Requirement for an aromatic amino acid or histidine at the $\mathrm{N}$ terminus of
Sindbis virus RNA polymerase, J. Virol. (1998) 72:2310-2315.

[141] Singh I.R., Suomalainen M., Varadarajan S., Garoff H., Helenius A., Multiple mechanisms for the inhibition of entry and uncoating of superinfecting Semliki Forest virus, Virology (1997) 231:59-71.

[142] Smithburn K.C., Hughs T.P., Burke A.W., Paul J.H., A neurotropic virus isolated from the blood of a native of Uganda, Am. J. Trop. Med. Hyg. (1940) 20:471-492.

[143] Solomon T., Vaughn D.W., Pathogenesis and clinical features of Japanese encephalitis and West Nile virus infections, Curr. Top. Microbiol. Immunol. (2002) 267:171-194.

[144] Spielman A., Andreadis T.G., Apperson C.S., Cornel A.J., Day J.F., Edman J.D., et al., Outbreak of West Nile virus in North America, Science (2004) 306:1473-1475.

[145] Steele K.E., Linn M.J., Schoepp R.J., Komar N., Geisbert T.W., Manduca R.M., et al., Pathology of fatal West Nile virus infections in native and exotic birds during the 1999 outbreak in New York City, New York, Vet. Pathol. (2000) 37:208-224.

[146] Sundin D.R., Beaty B.J., Interference to oral superinfection of Aedes triseriatus infected with La Crosse virus, Am. J. Trop. Med. Hyg. (1988) 38:428-432.

[147] Swayne D.E., Beck J.R., Smith C.S., Shieh W.J., Zaki S.R., Fatal encephalitis and myocarditis in young domestic geese (Anser anser domesticus) caused by West Nile virus, Emerg. Infect. Dis. (2001) 7:751-753.

[148] Taylor R.M., Hurlbut H.S., Dressler H.R., Spangler E.W., Thrasher D., Isolation of West Nile virus from Culex mosquitoes, J. Egypt Med. Assoc. (1953) 36:199-208.

[149] Taylor R.M., Work T.H., Hurlbut H.S., Rizk F., A study of the ecology of West Nile virus in Egypt, Am. J. Trop. Med. Hyg. (1956) 5:579-620.

[150] Tempelis C.H., Francy D.B., Hayes R.O., Lofy M.F., Variations in feeding patterns of seven culicine mosquitoes on vertebrate hosts in Weld and Larimer Counties, Colorado, Am. J. Trop. Med. Hyg. (1967) 16:111-119.

[151] Tesh R.B., Arroyo J., Travassos Da Rosa A.P., Guzman H., Xiao S.Y., Monath T.P., Efficacy of killed virus vaccine, live attenuated chimeric virus vaccine, and passive immunization for prevention of West Nile virus encephalitis in hamster model, Emerg. Infect. Dis. (2002) 8:1392-1397.

[152] Tesh R.B., Travassos da Rosa A.P., Guzman H., Araujo T.P., Xiao S.Y., Immunization with heterologous 
flaviviruses protective against fatal West Nile encephalitis, Emerg. Infect. Dis. (2002) 8:245-251.

[153] Tiawsirisup S., Platt K.B., Tucker B.J., Rowley W.A., Eastern cottontail rabbits (Sylvilagus floridanus) develop West Nile virus viremias sufficient for infecting select mosquito species, Vector Borne Zoonotic Dis. (2005) 5:342-350.

[154] Tsai T.F., Popovici F., Cernescu C., Campbell G.L., Nedelcu N.I., West Nile encephalitis epidemic in southeastern Romania, Lancet (1998) 352:767-771.

[155] Turell M.J., O’Guinn M., Oliver J., Potential for New York mosquitoes to transmit West Nile virus, Am. J. Trop. Med. Hyg. (2000) 62:413-414.

[156] Umrigar M.D., Pavri K.M., Comparative biological studies on Indian strains of West Nile virus isolated from different sources, Indian J. Med. Res. (1977) 65:596-602.

[157] Van Regenmortel M.H.V., Introduction to the species concept in virus taxonomy, in: van Regenmortel M.H.V., Fauquet C.M., Bishop D.H.L., Carstens E.B., Estes M.K., Lemon S.M., et al. (Eds.), Virus taxonomy, classification and nomenclature of viruses, , Seventh Report of the International Committee on Taxonomy of Viruses, Academic Press, San Diego, 2000, pp. 3-16.

[158] Verma S., Lo Y., Chapagain M., Lum S., Kumar M., Gurjav U., et al., West Nile virus infection modulates human brain microvascular endothelial cells tight junction proteins and cell adhesion molecules: transmigration across the in vitro blood-brain barrier, Virology (2009) 385:425-433.

[159] Weaver S.C., Brault A.C., Kang W., Holland J.J., Genetic and fitness changes accompanying adaptation of an arbovirus to vertebrate and invertebrate cells, J. Virol. (1999) 73:4316-4326.

[160] Weiner L.P., Cole G.A., Nathanson N., Experimental encephalitis following peripheral inoculation of West Nile virus in mice of different ages, J. Hyg. (Lond.) (1970) 68:435-446.

[161] Westaway E.G., Flavivirus replication strategy, Adv. Virus Res. (1987) 33:45-90.

[162] Westaway E.G., Mackenzie J.M., Khromykh A.A., Replication and gene function in Kunjin virus, Curr. Top. Microbiol. Immunol. (2002) 267:323-351.

[163] Wilcox B.R., Yabsley M.J., Ellis A.E., Stallknecht D.E., Gibbs S.E., West Nile virus antibody prevalence in American crows (Corvus brachyrhynchos) and fish crows (Corvus ossifragus) in Georgia, USA, Avian Dis. (2007) 51:125-128.

[164] Work T.H., Hurlbut H.S., Taylor R.M., Isolation of West Nile virus from hooded crow and rock pigeon in the Nile delta, Proc. Soc. Exp. Biol. Med. (1953) 84:719-722.

[165] Work T.H., Hurlbut H.S., Taylor R.M., Indigenous wild birds of the Nile Delta as potential West Nile virus circulating reservoirs, Am. J. Trop. Med. Hyg. (1955) 4:872-888.

[166] Xiao S.Y., Guzman H., Zhang H., Travassos da Rosa A.P., Tesh R.B., West Nile virus infection in the golden hamster (Mesocricetus auratus): a model for West Nile encephalitis, Emerg. Infect. Dis. (2001) 7:714-721.

[167] Xie H., Ryman K.D., Campbell G.A., Barrett A.D., Mutation in NS5 protein attenuates mouse neurovirulence of yellow fever 17D vaccine virus, J. Gen. Virol. (1998) 79:1895-1899. 